\title{
PERBEDAAN PENGARUH TEKNIK MARMET DENGAN PIJAT OKSITOSIN TERHADAP PRODUKSI ASI IBU POSTPARTUM DI RUMAH SAKIT IBU DAN ANAK IBI SURABAYA
}

\author{
SETIAWANDARI \\ Universitas Sebelas Maret Surakarta
}

\begin{abstract}
ABSTRAC
The Difference between the Influence of Mamet Technique and Oxytocin Massage toward the Production of Breast Milk of Postpartum Mother in the Mother and Child Hospital IBI Surabaya

Setiawandari $^{1)}$, DidikTamtomo ${ }^{2)}$, Hermanu Joebagio ${ }^{3)}$ Magister Kedokteran Keluarga Program Pascasarjana UNS setiawandari7@gmail.com
\end{abstract}

This research is motivated by the decrease of breast milk production of postpartum mother in the early breast feeding process that become a problem for mother to provide breast milk early on her baby. The delay of breast milk production could be stimulated by the use of intervention of mamet technique and oxytocin massage.

This study aims to understand the difference between the influence of mamet technique and oxcytocin massage toward the production of breast milk of the postpartum mother in RSIA IBI Surabaya.

This research is an experiment study using pre and post test only design with control group. Using a total sample technique, this research was conducted toward 40 postpartum mothers. The technique of data analysis applied in this study is normality data test, t-pair test, and t-independent test.

The result of this research shows that there has been an influenced of mamet technique toward the production of breast milk of those postpartum mothers $p=0,000$ and there has been influenced of oxytocin massage toward the production of breast milk of those postpartum mothers $p=0,000$. There is no difference influence between mamet technique and oxytocin massage toward the production of breast milk of the postpartum mothers $p=0,893$.

Based on the result, it can be concluded that: (1) mamet technique has increased the production of breast milk of the postpartum mother; (2) oxytocin massage has increased the production of breast milk of 
the postpartum mother; (3) there is no difference influence between mamet technique and oxytocin massage in increasing the production of breast milk of the postpartum mother in RSIA IBI Surabaya.

Keywords: mamet technique, oxytocin massage, breast milk production

\section{PENDAHULUAN}

\section{ASI merupakan makanan utama} bagi bayi, yang sangat dibutuhkan olehnya. Tidak ada makanan lainnya yang mampu menyaingi kandungan gizinya. ASI mengandung protein, lemak, gula, dan kalsium dengan kadar yang tepat. Dalam ASI juga terdapat zat antibodi, yang dapat melindungi bayi dari serangan penyakit selama ibu menyusuinya. Hal yang sama dinyatakan oleh WHO (2008) bahwa ASI adalah makanan pertama alami bagi bayi, ASI menyediakan seluruh energi dan nutrien yang dibutuhkan oleh bayi selama beberapa bulan pertama kehidupannya, dan terus menyediakannya hingga setengah atau lebih kebutuhan nutrisi anak selama enam bulan kedua kehidupan, dan hingga sepertiga selama tahun kedua kehidupan.
Menyusui adalah cara yang normal dan sehat untuk memberi makan bayi. Menyusui mencakup lebih dari sekedar memberi makan bayi dengan ASI. Menyusui penting bagi seluruh keluarga, secara emosional dan ekonomi, serta melindungi kesehatan ibu dengan beberapa cara. Hal ini sesuai dengan pendapat Poernomo (2004) yang mengatakan menyusui bukanlah sekedar memberikan air susu kepada bayi. Didalamnya tercakup kepercayaan, harapan, dan kebiasaan yang berlangsung secara turun menurun, diwariskan dari generasi.

Menurut Proverawati dan Rahmawati (2010) menyatakan : produksi ASI dapat meningkat dan menurun, salah satu diantaranya disebabkan oleh stimulasi pada kelenjar payudara terutama pada minggu pertama laktasi. Karena itu ibu dianjurkan 
menyusui dini agar isapan bayi segera menstimulasi hipofisis anterior untuk memproduksi hormon prolaktin dan hipofisis posterior untuk memproduksi hormon oksitosin. Hal ini senada dengan pendapat Varney (2008) yang menyatakan tanpa stimulasi puting susu, kadar prolaktin menurun sampai kadar pada wanita tidak hamil, dan tidak menyusui dua minggu. Menyusui melalui stimulasi puting susu memberi stimulasi terhadap pelepasan prolaktin.

Studi pendahuluan yang dilakukan di RSIA IBI pada bulan Agustus 2013, hasil wawancara dengan bidan mengatakan : Inisiasi Menyusu Dini sudah sejak awal program telah dilakukan pada setiap ibu bersalin yang melahirkan normal yang ditolong oleh bidan, hal ini dikarenakan kesadaran pentingnya manfaat menyusui dini di jam-jam pertama kelahiran bagi suksesnya pemberian ASI Eklusif di kemudian hari.

Pelaksanaan program ASI Eklusif di RSIA IBI Surabaya juga telah berjalan dan digalakkan pada setiap ibu yang melahirkan. Hal ini telah dibuktikan adanya pojok laktasi yang ada di ruang bayi dan ruang post partum dan tidak diberikannya susu formula pada bayi baru lahir selain ada indikasi. Melalui wawancara yang dilakukan kepada bidan yang ada di ruangan postpartum di RSIA IBI Surabaya mereka mengatakan tidak pernah melakukan teknik marmet dan pijat oksitosin pada saat memberikan perawatan kepada ibu post partum sebagai intervensi untuk melancarkan produksi ASI. Mereka lebih cenderung menggunakan terapi breast care dan terapi farmakologi untuk mengatasi masalah kurangnya produksi ASI pada ibu postpartum. 
Penurunan produksi ASI pada harihari pertama setelah melahirkan dapat disebabkan oleh kurangnya rangsangan hormon prolaktin dan oksitosin yang sangat berperan dalam kelancaran produksi ASI. Prolaktin dan oksitosin merupakan salah satu hormon pendukung dalam proses laktasi. Prolaktin adalah hormon esensial untuk penyempurnaan lobules-alveolus dalam kehamilan dan memulai sekresi air susu melalui reseptor pada dinding sel alveolus. Faktor inhibisi-prolaktin (prolactin-inhibiting factor, PIF) dari hipotalamus secara negative mengendalikan prolaktin, yang disekresikan oleh hipofisis (Varney, 2008). Sedangkan oksitosin merangsang pengeluaran susu dari payudara melalui kontraksi sel-sel miopitel di alveoli dan duktus (Cuningham, 2006). Apabila rangsangan produksi oksitosin dari hipofisis berkurang, pengeluaran ASI juga akan terhambat. Beberapa keadaan seperti stress maternal, keadaan bingung, takut dan cemas pada ibu dapat menghambat reflek let down (Dewi dan Sunarsih, 2011).

\section{Refleks oksitosin dapat dirangsang} melalui Inisiasi Menyusu Dini serta memerah dan memompa ASI 10-20 menit hingga bayi dapat menyusu. Teknik memerah ASI yang dianjurkan adalah menggunakan cara Cloe Marmet yang disebut dengan Teknik Marmet yang merupakan perpaduan antara teknik memerah dan memijat (Roesli, 2012). Teknik kombinasi antara cara memerah ASI dan memijat payudara menyebabkan reflek keluarnya ASI dapat optimal. Prinsipnya bertujuan untuk mengosongkan ASI dari sinus laktiferus yang berada dibawah areola sehingga diharapkan dengan pengosongan ASI pada daerah sinus laktiferus ini akan merangsang pengeluaran hormon prolaktin, pengeluaran hormone prolaktin ini selanjutnya akan merangsang mammary alveoli untuk memproduksi ASI. Senada 
dengan pendapat Manuaba (2007) memompa atau memerah ASI adalah usaha untuk menghindari kemungkinan lambatnya pengeluaran prolaktin. Dengan memompa atau memerah ASI dapat memberikan rangsangan pengeluaran prolaktin dan oksitosin. Demikian juga dengan pendapat Varney (2008) yang menyatakan masase payudara dan memerah ASI pada awalnya meningkatkan aliran ASI dengan membersihkan sinus-sinus dan duktus-duktus lakiferus kolostrum pertama yang lengket, selanjutnya membentuk aliran kolostrum yang kurang pekat. Kunci keberhasilan memerah ASI teknik marmet, yaitu memadukan pemijatan payudara sel-sel pembuat ASI dan saluran ASI untuk meningkatkan oksitosin - aliran ASI dengan memerah ASI (Roesli, 2012). Jika teknik ini dilakukan dengan efektif dan tepat maka tidak akan terjadi masalah pada produksi ASI. Tindakan tersebut dapat membantu memaksimalkan reseptor prolaktin dan meminimalkan efek samping dari tertundanya proses menyusui oleh bayi.

Selain usaha tersebut diatas, usaha untuk memperlancar produksi ASI dapat dilakukan juga dengan Pijat Oksitosin, yaitu pemijatan pada sepanjang tulang belakang (vertebrae) sampai tulang costae kelimakeenam dan merupakan usaha untuk merangsang hormon prolaktin dan oksitosin setelah melahirkan (WHO, 2011). Pijat oksitosin adalah tindakan yang dilakukan oleh suami/orang tua pada ibu menyusui yang berupa back massage pada punggung ibu untuk meningkatkan pengeluaran hormon oksitosin. Pijat oksitosin yang dilakukan oleh suami akan memberikan kenyamanan pada ibu sehingga akan memberikan kenyamanan pada bayi yang disusui (Suherni, dkk, 2007). Selain hal tersebut diatas, pijat oksitosin juga dapat mengurangi 
bengkak (engorgement), mengurangi sumbatan ASI, merangsang pelepasan hormone oksitosin, mempertahankan produksi ASI ketika ibu dan bayi sakit (Depkes RI, 2005).Tetapi usaha tersebut diatas tidak bisa dilakukan secara bersamaan, dikarenakan beberapa alasan. Untuk itu peneliti ingin mengetahui dari kedua teknik tersebut diatas, manakah yang paling efektif dalam membantu memperlancar produksi ASI ibu diawal menyusui. Sehingga ibu dapat benar-benar mau melakukan dan mendapat dukungan sepenuhnya dari keluarga serta dari petugas kesehatan (Bidan) dalam usaha memperlancar produksi ASI nya. Adapun tujuannya :

Menganalisis pengaruh Tehnik Marmet terhadap produksi ASI ibu postpartum di Rumah Sakit Ibu dan Anak IBI Surabaya
Menganalisis pengaruh Pijat Oksitosin terhadap produksi ASI ibu postpartum di Rumah Sakit Ibu dan Anak IBI Surabaya

Menganalisis perbedaan antara Teknik Marmet dengan Pijat Oksitosin terhadap produksi ASI ibu postpartum di Rumah Sakit Ibu dan Anak IBI Surabaya.

\section{METODE PENELITIAN}

Penelitian ini dilakukan di Rumah Sakit Ibu dan Anak IBI Surabaya pada bulan Agustus 2013 s/d Januari 2014.

Jenis penelitian ini adalah true eksperimen dengan desain penelitian pretest posttest with control group design. Populasi pada penelitian ini adalah semua ibu postpartum yang melahirkan normal di Rumah Sakit Ibu dan Anak IBI Surabaya pada 
bulan September-November 2013 dengan besar sampel 40 orang. Pengambilan sampel menggunakan metode total sampling, kemudian dilakukan randomisasi untuk menentukan sampel mana yang masuk ke dalam kelompok intervensi teknik marmet atau pijat oksitosin.

Variabel independent dalam penelitian ini adalah teknik marmet dengan pijat oksitosin. Sedangkan variabel dependent dalam penelitin ini adalah produksi ASI.

Teknik Marmet adalah teknik mengeluarkan ASI pada ibu post partum hari ke 1-3 dengan cara kombinasi antara memerah dan memijat payudara. Skala : Nominal.

Pijat Oksitosin adalah memijat bagian punggung ibu postpartum hari 1-3 pada sisi tulang belakang dari leher sampai tulang belikat. Skala : Nominal.

Produksi ASI adalah banyaknya ASI ibu post partum yang keluar, diukur dengan menggunakan indikator utama yaitu BB Bayi yang ditimbang pada hari ke 1 ke 7 dan ke14 (Berat badan bayi sesuai dengan BB lahir atau naik), dan indicator penunjang yaitu frekuensi BAK 6-8 $\mathrm{x} /$ hari, frekuensi menyusui $8-12 \mathrm{x} / \mathrm{hari}$, dan bayi tidur nyenyak 2-3 jam setelah disusui. Alat ukur : timbangan bayi digital. Cara ukur: observasi dan kuesioner. Skala = Rasio.

Teknik analisis data, sebelum dilakukan uji statistik, peneliti melakukan uji normalitas data dengan kolmogorov smirnov dengan bantuan SPSS 16. Jika $\rho>\alpha(0.05)$ maka dapat disimpulkan data berdistribusi normal. 
HASIL DAN ANALISIS PENELITIAN

Tabel 1.1 Hasil Uji Normalitas One Sample Kolmogorov-Smirnov Test

\begin{tabular}{|c|c|c|}
\hline & & $\mathrm{BBL}$ \\
\hline $\mathrm{N}$ & & 40 \\
\hline Normal Parameters ${ }^{\mathrm{a}}$ & Mean & 2975.92 \\
\hline & $\begin{array}{l}\text { Std. } \\
\text { Deviation }\end{array}$ & 286.008 \\
\hline Most & e Absolute & .129 \\
\hline Differences & Positive & .120 \\
\hline & Negative & -.129 \\
\hline \multirow{3}{*}{\multicolumn{2}{|c|}{$\begin{array}{l}\text { Kolmogorov-Smirnov Z } \\
\text { Asymp. Sig. (2-tailed) }\end{array}$}} & .813 \\
\hline & & \\
\hline & & 522 \\
\hline
\end{tabular}

a. Test distribution is Normal.

Tabel 1.2 Hasil Analisis Uji Hipotesis T Pair pada Teknik Marmet Terhadap Produksi ASI Ibu Postpartum di RSIA IBI Surabaya

Paired Samples Test

\begin{tabular}{|c|c|c|c|c|c|c|c|c|c|}
\hline & \multicolumn{5}{|c|}{ Paired Differences } & \multirow[b]{3}{*}{$\mathrm{t}$} & \multirow[b]{3}{*}{ df } & \multirow{3}{*}{$\begin{array}{l}\text { Sig. (2- } \\
\text { tailed) }\end{array}$} \\
\hline & & \multirow[b]{2}{*}{ Mean } & \multirow{2}{*}{$\begin{array}{l}\text { Std. } \\
\text { Deviatio } \\
n\end{array}$} & \multirow{2}{*}{$\begin{array}{l}\text { Std. } \\
\text { Error } \\
\text { Mean }\end{array}$} & \multicolumn{2}{|c|}{$\begin{array}{l}95 \% \text { Confidence } \\
\text { Interval of the } \\
\text { Difference }\end{array}$} & & & \\
\hline & & & & & Lower & Upper & & & \\
\hline Pair 1 & $\begin{array}{l}\text { BBL } \\
\text { BB14hari }\end{array}$ & -93.650 & 89.243 & 19.955 & -135.417 & -51.883 & -4.693 & 19 & .000 \\
\hline
\end{tabular}

Berdasarkan tabel 1.2 didapatkan $\rho=$ yang signifikan teknik marmet terhadap 0,000. Dengan demikian nilai $\rho$ lebih kecil dari produksi ASI ibu postpartum di RSIA IBI nilai $\alpha(5 \%)$ atau 0,05 sehingga Ha diterima dan Surabaya.

Ho ditolak. Dapat disimpulkan ada pengaruh
Berdasarkan uji normalitas didapatkan nilai $\rho=0,522$. Hal ini berarti nilai $\rho>0,05$ yang menunjukkan bahwa data berdistribusi normal. 
Tabel 1.3 Hasil Analisis Uji Hipotesis T Pair pada Pijat Oksitosin Terhadap Produksi ASI Ibu Postpartum di RSIA IBI Surabaya

Paired Samples Test

\begin{tabular}{|c|c|c|c|c|c|c|c|c|c|}
\hline & & \multicolumn{5}{|c|}{ Paired Differences } & \multirow[b]{3}{*}{$\mathrm{t}$} & \multirow[b]{3}{*}{ df } & \multirow{3}{*}{$\begin{array}{l}\text { Sig. } \\
\text { tailed) }\end{array}$} \\
\hline & & \multirow[b]{2}{*}{ Mean } & \multirow{2}{*}{$\begin{array}{l}\text { Std. } \\
\text { Deviat } \\
\text { ion }\end{array}$} & \multirow{2}{*}{$\begin{array}{l}\text { Std. } \\
\text { Error } \\
\text { Mean }\end{array}$} & \multicolumn{2}{|c|}{$\begin{array}{l}95 \% \text { Confidence } \\
\text { Interval of the } \\
\text { Difference }\end{array}$} & & & \\
\hline & & & & & Lower & Upper & & & \\
\hline air 1 & $\begin{array}{l}\text { BBL } \\
\text { BB14hari }\end{array}$ & -106.600 & 71.977 & 16.095 & -140.286 & -72.914 & -6.623 & 19 & .000 \\
\hline
\end{tabular}

Berdasarkan tabel 1.3 didapatkan $\rho=$ ada pengaruh yang signifikan pijat oksitosin 0,000. Dengan demikian nilai $\rho$ lebih kecil terhadap produksi ASI ibu postpartum di dari nilai $\alpha(5 \%)$ atau 0,05 sehingga $\mathrm{Ha} \quad$ RSIA IBI Surabaya. diterima dan Ho ditolak. Dapat disimpulkan 
Tabel 1.4 Hasil Analisis Uji Hipotesis Independent Samples Test

Independent Samples Test

\begin{tabular}{|c|c|c|c|c|c|c|c|c|c|c|}
\hline & \multicolumn{2}{|c|}{\begin{tabular}{|l|} 
Levene's Test \\
for Equality of \\
Variances
\end{tabular}} & \multicolumn{7}{|c|}{ t-test for Equality of Means } \\
\hline & & \multirow[b]{2}{*}{$\mathrm{F}$} & \multirow[b]{2}{*}{ Sig. } & \multirow[b]{2}{*}{$\mathrm{t}$} & \multirow[b]{2}{*}{ df } & \multirow{2}{*}{$\begin{array}{l}\text { Sig. } \\
(2- \\
\text { tailed })\end{array}$} & \multirow{2}{*}{\begin{tabular}{|l} 
Mean \\
Difference
\end{tabular}} & \multirow{2}{*}{\begin{tabular}{|l} 
Std. \\
Error \\
Differenc \\
e
\end{tabular}} & \multicolumn{2}{|c|}{$\begin{array}{ll}95 \% & \text { Confidence } \\
\text { Interval of the } \\
\text { Difference }\end{array}$} \\
\hline & & & & & & & & & Lower & Upper \\
\hline BB14hari & $\begin{array}{l}\text { Equal } \\
\text { variances } \\
\text { assumed }\end{array}$ & 4.662 & .037 & .136 & 38 & 893 & 13.000 & 95.577 & -180.486 & 206.486 \\
\hline & $\begin{array}{l}\text { Equal } \\
\text { variances } \\
\text { not } \\
\text { assumed }\end{array}$ & & & .136 & 35.155 & .893 & 13.000 & 95.577 & -181.002 & 207.002 \\
\hline
\end{tabular}


Berdasarkan analisis diatas pada ibu yang tidak teratur memompa didapatkan pada kelompok teknik marmet payudaranya. Kombinasi memompa dan $\rho=0,893$. Sedangkan pada kelompok pijat memijat payudara lebih efektif dalam oksitosin $\rho=0,893$. Dengan demikian nilai $\rho$ lebih besar dari nilai $\alpha(5 \%)$ atau 0,05 sehingga Ho diterima dan Ha ditolak. Dapat disimpulkan tidak terdapat perbedaan yang signifikan antara teknik marmet dengan pijat oksitosin terhadap produksi ASI ibu postpartum di RSIA IBI Surabaya.

\section{PEMBAHASAN}

\author{
Pengaruh Teknik Marmet Terhadap \\ Produksi ASI Ibu Postpartum
}

Ada pengaruh teknik marmet terhadap produksi ASI ibu postpartum di RSIA IBI Surabaya. Hasil tersebut didukung oleh penelitian yang dilakukan oleh E Jones, dkk (2001) yang berjudul “ $A$ randomised controlled trial to compare methods of milk expression after preterm delivery”. Hasil penelitian menunjukkan ibu yang memompa payudaranya secara teratur lebih lancar produksi ASI nya dari memproduksi ASI dan dianjurkan pada ibu yang bayinya sakit atau lahir premature.

Hal ini sependapat dengan hasil penelitian Desmayanti (2008) yang berjudul "Efektifitas Kombinasi Areolla Massage dengan Rolling Massage Terhadap Pengeluaran ASI Secara Dini Pada Ibu Post SC di Puskesmas Pamulang dan Cikupa Banten”. Hasil penelitian menunjukkan ibu-ibu yang diberi intervensi kombinasi areolla massage dengan rolling massage mempunyai peluang 5,146 kali untuk terjadi pengeluaran ASI kurang dari 12 jam. Artinya intervensi areolla massage dengan rolling massage efektif dalam menstimulasi hipofise anterior dan posterior mensekresi hormon prolaktin dan oksitosin di awal menyusui. Senada dengan hasil penelitian Sefi Rachma Afianti (2012) yang meneliti tentang "Efektivitas Pemijatan Payudara Dengan 
Senam Payudara Terhadap Kelancaran

Pengeluaran ASI Pada Ibu Post Partum”. Hasil penelitian menunjukkan tidak ada perbedaan yang signifikan antara pemijatan payudara dan senam payudara terhadap pengeluaran kelancaran ASI pada ibu post partum.

Ada banyak hal yang mempengaruhi produksi ASI, salah satu diantaranya perawatan payudara. Perawatan payudara yang tepat diawal menyusui bisa merangsang payudara untuk memproduksi ASI lebih dini dan banyak. Dengan perawatan payudara dalam hal ini teknik marmet, hipofisis dipengaruhi untuk mengeluarkan hormon prolaktin dan oksitosin. Kedua hormon inilah yang berperan besar dalam produksi ASI. Hal tersebut mengacu teori Manuaba (2007) yang mengatakan bahwa perawatan payudara adalah usaha untuk menghindari kemungkinana lambatnya pengeluaran prolaktin. Dengan merawat payudara (memerah, memijat, memompa, kompres hangat, senam payudara, dsb) dapat memberikan rangsangan pengeluaran prolaktin dan oksitosin.

Produksi ASI juga dipengaruhi oleh frekuensi menyusui, semakin sering menyusui akan semakin meningkatkan produksi ASI. Menurut Khasanah (2010) menyatakan bahwa berdasarkan hasil penelitian, produksi ASI akan optimal ketika ibu menyusui bayinya 5 kali atau lebih per hari selama 1 bulan awal menyusui. Menyusui yang tidak terjadwal atau menyusui keinginan bayi (on demand), dapat meningkatkan produksi ASI pada minggu pertama. Hal tersebut mengacu pada teori Manajemen Laktasi (WHO,2011) tentang milk production reflek dan let down reflex. Milk production reflek yaitu ketika bayi menyusu, rangsangan sensorik dari puting payudara tersebut dikirim ke otak. Sebagai jawabannya, bagian depan (anterior) kelenjar pituitary didasar otak mengeluarkan prolaktin. Prolaktin masuk ke dalam darah menuju payudara, dan menyebabkan sel-sel pembuat ASI 
memproduksi ASI. Sedangkan let down reflex yaitu ketika bayi menyusu, rangsangan sensorik dikirim ke otak. Sebagai jawabannya bagian belakang kelenjar pituitary di dasar otak mengeluarkan hormone oksitosin.

Oksitosin masuk ke pembuluh darah menuju payudara, merangsang sel-sel otot (mioepitelium) disekeliling alveoli berkontraksi. Kontraksi ini membuat ASI yang telah terkumpul di alveoli mengalir sepanjang duktus laktiferus menuju ke puting masuk ke dalam mulut bayi.

Tetapi kenyataan dilapangan, tidak jarang pada hari pertama sampai hari ketiga, bayi mengalami kondisi banyak tidur sedikit menyusu. Berkurangnya rangsangan menyusui oleh bayi diawal pospartum misalnya dikarenakan bayi malas menghisap, kekuatan isapan yang kurang, frekuensi isapan yang kurang dan singkatnya waktu menyusui menyebabkan pelepasan prolaktin dan oksitosin dari hipofisis berkurang sehingga ASI tidak segera diproduksi. Oleh sebab itu perawatan payudara dalam hal ini teknik marmet diawal menyusui adalah salah satu metode yang bisa membantu menambah frekuensi isapan bayi yang kurang. Dengan kombinasi gerakan memerah dan memijat yang dilakukan minimal $2 \mathrm{x}$ dalam sehari akan membuat duktus melebar dan menjadi lunak, juga membantu menstimulasi saraf hipotalamus untuk segera mengeluarkan hormon prolaktin dan oksitosin, sehingga produksi ASI tidak terlambat. Hal ini sesuai dengan teori dari Roesli (2012) yang mengatakan perawatan payudara dengan teknik marmet bertujuan untuk mengosongkan ASI dari sinus laktiferus yang berada dibawah areola sehingga diharapkan dengan pengosongan ASI pada daerah sinus laktiferus ini akan merangsang pengeluaran hormon prolaktin, pengeluaran hormon prolaktin ini selanjutnya akan merangsang mammary alveoli untuk memproduksi ASI.

Pengaruh Pijat Oksitosin Terhadap Produksi ASI Ibu Postpartum 
Ada pengaruh pijat oksitosin terhadap produksi ASI ibu postpartum di RSIA IBI Surabaya. Hal ini sesuai dengan hasil penelitia Budiarti (2009) yang berjudul "Hubungan Pemberian Paket Sukses ASI Terhadap Produksi ASI Pada Ibu Postpartum Dengan Seksio Sesaria di wilayah Depok Jawa Barat”. Adapun salah satu isi dari paket sukses ASI adalah pemberian intervensi pijat oksitosin pada masa 24 jam setelah operasi sampai dengan hari ketiga setelah operasi. Hasil penelitian menyatakan ada hubungan yang bermakna antara pemberian paket "Sukses ASI " terhadap kelancaran produksi ASI baik dari indikator bayi maupun dari indikator ibu.

Senada dengan hasil penelitian Syswianti, D (2009) yang berjudul “The Influence of Massage Oxytosin Against The Success of Breastfeeding Process on Material Chilbed of Maternal Breastfeeding at PKU Muhammadiyah Bantul Hospital in 2009". Hasil penelitian menunjukkan pemberian pijat oksitosin pada kelompok perlakuan berhasil meningkatkan pemberian ASI dengan signifikan $\mathrm{p}=0,004$. Hal ini membuktikan pemberian pijat oksitosin mempengaruhi keberhasilan proses menyusui pada ibu nifas daripada ibu nifas yang hanya melakukan perawatan putting susu dengan baby oil.

Pelepasan hormon oksitosin dari kelenjar hipofisis posterior dapat distimulasi dengan pemijatan sepanjang tulang belakang (vertebrae) sampai tulang costae kelima-keenam ibu. Hal ini sesuai dengan teori yang dikemukanan oleh Roesli (2011), oksitosin adalah hormon yang diproduksi di hipotalamus dan diangkut lewat aliran aksoplasmed ke hipofisis posterior yang jika mendapatkan stimulasi yang tepat hormon ini akan dilepas kedalam darah. Peranan fisiologi lain yang dimiliki oleh hormon ini adalah meningkatkan pengeluaran ASI dari kelenjar mammae. Impuls neural dari pemijatan sepanjang tulang belakang 
merupakan stimulus bagi pelepasan oksitosin.

Selain menstimulasi pengeluaran hormon oksitosin, pemijatan sepanjang tulang belakang juga memberikan rasa nyaman pada ibu. Hal ini sejalan dengan pendapat Nurchayati (2012) dalam penelitiannya "Manfaat Massaging Nafe (Pemijatan Tengkuk) Terhadap Pengeluaran ASI Pada Ibu Nifas di RSUD Cilacap” yang menyatakan rasa nyaman yang ibu rasakan akan membantu dalam pengeluaran ASI sehingga ibu tidak merasakan nyeri baik dari hisapan bayi pada payudara maupun kontraksi uterus karena pada pemijatan tengkuk mampu mengeluarkan endorphin . Endorphin merupakan senyawa yang menenangkan. Dalam keadaan tenang seperti inilah ibu nifas yang sedang menyusui mampu mempertahankan produksi ASI yang mencukupi bagi bayinya. Hal ini mengacu pada teori Sloane (2003), peranan hipofisis adalah mengeluarkan endorphin (endegenous opiates) yang berasal dari dalam tubuh dan efeknya menyerupai heroin dan morfin. Zat ini berkaitan dengan penghilang nyeri alamiah.

Rasa nyaman yang dirasakan ibu selain dikarenakan efek dari pemijatan, juga dikarenakan pijat oksitosin pada ibu postpartum membutuhkan bantuan orang lain atau mengikutsertakan peran ayah maupun anggota keluarga lain seperti orang tua. Hal inilah yang membuat ibu menyusui merasa nyaman, yakin dan percaya diri bahwa kehadiran bayinya memang diharapkan semua pihak. Karena pada dasarnya proses menyusui merupakan interaksi emosional bersama, sehingga rasa percaya diri, afektif dan interaksi sosial lebih terjadi dengan baik. Sejalan dengan pendapat Roesli (2011) pemberian ASI tidak hanya sekedar proses berdua antara ibu dengan bayi, akan tetapi keberadaan seorang ayah akan sangat membantu. Ketenangan jiwa ibu akan meningkatkan refleks let down, begitu juga sebaliknya apabila ibu dalam kondisi mengalami gangguan emosi (takut, cemas, binggung) 
akan menghambat refleks let down. Hal ini mengacu pada teori oleh Soetjiningsih (2012) yang menyatakan bahwa bila ada stress pada ibu yang menyusui maka akan terjadi suatu blokade dari refleks let down. Ini disebabkan oleh karena adanya pelepasan dari adrenalin (epinefrin) yang menyebabkan vasokontriksi dari pembuluh darah alveoli, sehingga oksitosin sedikit harapannya untuk mencapai target organ mioepitelium. Oleh karena itu rasa aman, nyaman, dan rasa percaya diri sangat diperlukan pada ibu yang menyusui, guna meningkatkan produksi ASI-nya.

Perbedaan Pengaruh Antara Teknik Marmet Dengan Pijat Oksitosin Terhadap Produksi ASI Ibu Postpartum

Tidak ada perbedaan pengaruh teknik marmet dengan pijat oksitosin terhadap peningkatan produksi ASI ibu postpartum di RSIA IBI Surabaya. Kedua intervensi sama-sama efektif dalam peningkatan produksi ASI postpartum. Hasil penelitian ini didukung oleh penelitian yang dilakukan oleh Mardiyaningsih, E (2010) yang berjudul "Efektifitas Kombinasi Teknik Marmet Dan Pijat Oksitosin Terhadap Produksi ASI Ibu Postpartum Dengan Seksio Sesaria Di Rumah Sakit Wilayah Jawa Tengah”. Hasil penelitian menyatakan ada perbedaan proporsi kelancaran produksi ASI antara kelompok kontrol dan kelompok intervensi dengan $\rho$ value $=$ 0,000 dan ibu seksio sesarea yang diberikan kombinasi teknik marmet dan pijat oksitosin berpeluang 11,5 kali lebih besar untuk mempunyai produksi ASI lancar dibandingkan dengan kelompok kontrol $(\mathrm{OR}=11,500)$.

Hal senada juga dinyatakan oleh Purnama (2013) dalam penelitiannya yang berjudul "Perbedaan Efektivitas Antara Pijat Oksitosin Dan Breast Care Terhadap Produksi ASI Pada Ibu Post Partum Dengan SC di RSUD Banyumas". Hasil penelitiannya menyatakan bahwa tidak terdapat perbedaan yang signifikan antara pijat oksitosin dan breast care terhadap 
produksi ASI pada ibu post partum dengan

SC di RSUD Banyumas. Artinya ibu postpartum yang dengan segera mendapatkan usaha untuk melancarkan atau meningkatkan produksi ASI baik dengan cara pijat oksitosin atau breast care akan lebih baik daripada ibu postpartum yang tidak mendapatkan intervensi sama sekali

Kenyataan yang ada di masyarakat menunjukkan bahwa produksi ASI dan ejeksi ASI yang sedikit pada hari-hari pertama melahirkan menjadi kendala dalam pemberian ASI secara dini. Tidak keluarnya produksi ASI pada hari-hari pertama setelah melahirkan menyebabkan ibu dan keluarga memberikan susu formula (prelactal feeding). Bila prelactal feeding diberikan pada bayi, maka ASI terbentuk lebih lambat, karena bayi tidak cukup kuat menghisap puting payudara ibu. Hal ini menyebabkan bayi enggan untuk menyusu, sehingga tidak ada stimulasi hipofisis untuk memproduksi ASI. Sejalan dengan pendapat Prasetyono
(2005) yang menyatakan : segera setelah dilahirkan, bayi harus di susukan kepada ibunya, tindakan ini bukan dimaksudkan untuk memberikan nutrisi, tetapi agar bayi belajar menyusui atau menghisap puting payudara ibu, serta mendukung produksi ASI. Gerakan refleks bayi baru lahir, yang menghisap puting payudara ibu akan mencapai puncaknya pada 20-30 menit setelah kelahirn bayi. Jika ibu terlambat menyusui bayinya, maka refleks itu akan berkurang.

Peran tenaga kesehatan dalam memberikan dukungan psikologis, tidak bisa dilepaskan dari usaha ibu dalam meningkatkan produksi ASI-nya. Pemberian nasihat dan penyuluhan tentang ASI perlu diberikan terutama pada ibu-ibu yang baru pertama kali mempunyai anak, dan belum mengetahui cara menyusu yang benar. Begitu juga pemberian intervensi tentang perawatan payudara sangat penting. Sehingga masalah menyusui yang muncul pada hari-hari pertama menyusui seperti produksi ASI sedikit, ASI tidak 
lancar dan ASI tidak keluar dapat diatasi.

Beberapa intervensi perawatan payudara diantaranya adalah teknik marmet dan pijat oksitosin. Kedua intervensi mempunyai kelebihan masing-masing, pada teknik marmet ibu bisa melakukan sendiri tanpa bantuan orang lain. Sehingga ibu lebih percaya diri bahwa dirinya mampu merawat payudaranya dan dapat memberikan ASI sesuai dengan kebutuhan bayinya. Hal ini didukung oleh pendapat Khasanah (2010) yang mengatakan menyusui dapat memberi rasa percaya diri bahwa ibu mampu menyusui dengan produksi ASI yang mencukupi untuk bayinya. Menyusui dipengaruhi oleh emosi ibu dan kasih sayang terhadap bayi sehingga bisa meningkatkan produksi hormon, terutama oksitosin yang pada akhirnya akan meningkatkan produksi ASI.

Sedangkan pada intervensi pijat oksitosin, ibu dibantu oleh suami atau anggota keluarga yang lain. Keberhasilan pemberian ASI ditentukan oleh peran keluarga, terutama ayah atau suami.

Selama proses ini berlangsung, peran ayah sama pentingnya dengan peran ibu. Peran ayah yang paling utama adalah menciptakan suasana dan situasi kondusif yang memungkinkan pemberian ASI berjalan lancar. Hal tersebut sesuai dengan pendapat Suherni (2007) yang menyatakan pijat oksitosin adalah tindakan yang dilakukan oleh suami/orang tua pada ibu menyusui yang berupa back massage pada punggung ibu untuk meningkatkan pengeluaran hormon oksitosin. Pijat oksitosin yang dilakukan oleh suami akan memberikan kenyamanan pada ibu dan pada bayi yang disusui.

Semakin sering bayi menyusu dan semakin kuat daya isap bayi, maka payudara akan memproduksi ASI lebih banyak. Semakin sering ibu melakukan intervensi teknik marmet atau pijat oksitosin pada awal menyusui, semakin awal ASI diproduksi dan semakin meningkat produksinya, sehingga ibu dapat memberikan ASI kepada bayinya 
dengan cukup. Dengan begitu, ibu dapat menyusui bayinya secara murni selama 6 bulan dan tetap memberikan ASI sampai si anak berusia dua tahun. Segala bentuk perawatan payudara atau stimulasi yang dilakukan oleh ibu postpartum sebagai usaha untuk meningkatkan produksi ASInya, akan lebih baik hasil dan manfaatnya bagi ibu dan bayinya daripada ibu yang tidak melakukan stimulasi.

\section{SIMPULAN DAN SARAN}

Dapat disimpulkan bahwa :

Teknik marmet meningkatkan produksi ASI ibu postpartum di RSIA IBI Surabaya.

Pijat oksitosin meningkatkan produksi ASI ibu postpartum di RSIA IBI Surabaya.

Tidak ada perbedaan pengaruh teknik marmet dengan pijat oksitosin dalam meningkatkan produksi ASI ibu postpartum di RSIA IBI Surabaya.

Untuk itu sarannya adalah :

\section{Bagi tempat penelitian}

Perlu mengupayakan pelatihan manajemen laktasi, khususnya tentang teknik marmet dan pijat oksitosin kepada seluruh bidan agar terampil dan terlatih dalam memberikan asuhan kebidanan pada ibu nifas, guna meningkatkan produksi ASI pada ibu postpartum.

\section{Bagi bidan dan profesi}

Diharapkan Bidan dapat menjadikan kedua metode alternative dalam mengatasi masalah awal pada ibu menyusui. Diharapkan Bidan dapat menjadikan kedua metode alternative dalam mengatasi masalah awal pada ibu menyusui. Disarankan kedua metode dilakukan secara kombinasi karena akan lebih efektik dalam meningkatkan produksi ASI di awal masa menyusui.

\section{Bagi peneliti}

Sebagai bahan masukan bagi peneliti selanjutnya, perlu penelitian lebih lanjut tentang metode-metode lain yang dapat berkontribusi dalam penggalakan 
pemberian ASI. Dan akan semakin baik jika dapat mengukur kadar oksitosin untuk mengetahui jumlah peningkatan pelepasan oksitosin saat dilakukan intervensi.

\section{DAFTAR PUSTAKA}

Afianti,S.R. 2012. “Efektivitas Pemijatan Payudara Dengan Senam Payudara Terhadap Kelancaran Pengeluaran ASI Pada Ibu Post Partum”.

Budiarti. 2009. "Hubungan Pemberian Paket Sukses ASI Terhadap Produksi ASI Pada Ibu Postpartum Dengan Seksio Sesaria di wilayah Depok Jawa Barat”.

Cunningham (2006). Obstetri Williams. Jakarta: EGC

E Jones, dkk. 2001. “A randomised controlled trial to compare methods of milk expression after preterm delivery". Journal List Arch Dis Child Fetal Neonatal Ed 2001;85:F91-F95.
Desmayanti. 2008. "Efektifitas

Kombinasi Areolla Massage dengan Rolling Massage Terhadap Pengeluaran ASI Secara Dini Pada Ibu Post SC di Puskesmas Pamulang dan Cikupa Banten”.

Depkes, 2005. Manajemen Laktasi; Buku Panduan bagi Bidan dan Petugas Kesehatan di Puskesmas. Jakarta: Direktorat Gizi Masyarakat.

Dewi, Sunaseh (2011). Asuhan Kebidanan Pada Ibu Nifas. Jakarta : Salemba Empat.

Khasanah, N. 2011. Asia atau Susu Formula Ya? Panduan Lengkap Seputar ASI dan Susu Formula. Jogjakarta : Flash Books.

$$
\text { Mardiyaningsih, } \quad \text { E. } 2010 .
$$

"Efektifitas Kombinasi Teknik Marmet Dan Pijat Oksitosin Terhadap Produksi ASI Ibu Postpartum Dengan Seksio Sesaria Di Rumah Sakit Wilayah Jawa Tengah". Jounal FIK UI. 
Manuaba, 2007. Pengantar Kuliah

Obstetri. Jakarta : EGC.

Nurchayati, 2012. Manfaat Massaging

Nape (Pemijatan Tengkuk) Terhadap

Pengeluaran ASI Pada Ibu Nifas Di RSUD

Cilacap. KTI Akademi Kebidanan Graha

Mandiri Cilacap. KTI Akademi Kebidanan

Graha Mandiri Cilacap.

Purnama, 2013. Efektifitas antara pijat

oksitosin dan breast care terhadap produksi

asi pada ibu post partum dengan sectio

caesarea di RSUD Banyumas. Skripsi

Universitas Jendral Sudirman. Jawa

Tengah.

Proverawati, A;dkk. 2010. Kapita Selekta

ASI dan Menyusui. Yogyakrt : Nuha

Medika.

Prasetyono, DS. 2009. Buku Pintar ASI

Eksklusif. Jogjakarta: DIVA Press.

Roesli, U. 2012. Panduan Konseling

Menyusui. Cetakan IV. Jakarta: Pustaka

Bunda.
Suherni, 2007. Perawatan Masa Nifas.

Yogyakarta: Fitramaya

Soetjiningsih, 2012. Seri Gizi Klinik ASI

Petunjuk Untuk Tenaga Kesehatan. Jakarta

: EGC.

Syswianti, D, at all (2009). The Influence

of Massage Oxytosin Against The

Success of Breastfeeding Process on

Material Chilbed of Maternal

Breastfeeding at PKU Muhammadiyah

Bantul Hospital in 2009. Jurnal

Kepmenkes Poltekes Yogyakarta. Posted

on March 12, 2012.

WHO.2011. Pelatihan Konseling

Menyusui Modul 40 jam WHO dan

UNICEF. AIMI Jatim.

Varney, H; dkk. 2008. Buku Ajar Asuhan

Kebidanan Edisi. 4 Volume.2. Jakarta :

EGC 